Department of Anatomy (Prof. H. Fujita), Hiroshima University School of Medicine, Hiroshima, and Department of Anatomy (Prof. N. OTsuka), Okayama University School of Medicine, Okayama, Japan

\title{
Freeze-Etching Images of Rabbit Thyroid Glands
}

\author{
Hisao Fujita, Hiromu Mishima and Nagayasu Otsuka
}

Received July 7, 1975

\begin{abstract}
Summary. Freeze-etching images of the rabbit thyroid were described. The outline of the structure of the follicular epithelial cell in freeze-etching techniques is consistent with that in ultrathin sections. The subapical junctional complex consists of tight and gap junctions. According to the number of strands (5-16) indicating the tight junction and the depth of the tight junction (0.3-1.1 $\mu \mathrm{m})$, this is classified into the "very tight" form of CLAUDE and GOODENOUGH (1973). The number of intramembranous particles per $\mu \mathrm{m}^{2}$ on the A-face of the lateral as well as the apical plasma membrane is far larger than that on the B-face. The limiting membrane of the reabsorbed colloid droplet shows also a similar pattern to that of the plasma membrane. The capillary endothelial cells show numerous fenestrations whose population density is about $20 / \mu \mathrm{m}^{2}$ on the endothelial surface except in the parajunctional zone.
\end{abstract}

Though numerous papers have been published as to the fine structure and the functional properties of the thyroid gland, many problems remain to be solved by the use of recent improved technique. Since the freeze-etching method was applied to cytological studies (Moor and MüHLETHALER, 1963), many important facts have been discovered in the fine structure of the cell. As far as is known from the literature available, the freeze-etching technique has not yet been used for the study of the mammalian thyroid except for the report on the parafollicular cell by ВuсннеIм and WELSCH (1972). The aim of the present paper is to describe the freeze-etching images of the following pertaining to the thyroid gland: (1) general view of the thyroid, (2) details of the junctional morphology of the follicular epithelium, (3) structures of the plasma membrane of the follicular epithelial cell and of the limiting membrane of the colloid droplet, and (4) structures of the capillary endothelium.

\section{Materials and Methods}

Thyroid glands of six adult male rabbits were used for this study. Three of them were injected intravenously with 5 units of Thytropar (Armour) and sacrificed 0.5, 1 , and $2 \mathrm{hrs}$ after the injection. The thyroids of these animals were immersed for 4-6 hrs in $3 \%$ glutaraldehyde solution buffered at $\mathrm{pH} 7.4$ with MiLlonIG's phosphate. After fixation, pieces of the tissue were rinsed in the phosphate buffer, soaked in $30 \%$ glycerol solution for $12 \mathrm{hrs}$, and frozen in liquid Freon cooled with liquid nitrogen. Platinum-carbon replicas were made in a JEE-FED type freeze-etching apparatus and examined in a Hitachi HU-11D electron microscope. 


\section{Observations}

\section{Outline}

After preparation by the freeze-etching method the thyroid gland shows, as in thin sections, a follicle structure consisting of follicular epithelial cells and follicular lumen (Fig. 1). In addition to this, parafollicular cells and interfollicular connective tissues containing blood capillaries are seen.

The follicular epithelial cell has a round nucleus, well developed rough endoplasmic reticulum, Golgi apparatus, mitochondria, secretory granules, reabsorbed colloid droplets and numerous microvilli (Fig. 2). The profiles of well developed rough endoplasmic reticulum in the basal part of the cytoplasm and the production of secretory granules in the Golgi apparatus are quite consistent with those of the fine structural image obtained by ultrathin sections (Fig. 1). The secretory granules round in shape and about $200 \mathrm{~nm}$ in diameter which have been believed to contain thyroglobulin are localized at the apical part of the cell. The nuclear pores are distributed irregularly on the nuclear membrane and their population is $6.3 \pm 2.5 / \mu \mathrm{m}^{2}$ in normal rabbits. Microvilli are quite numerous on their apical surface (Fig. 3) and some of their dimensional data are shown in Table 1.

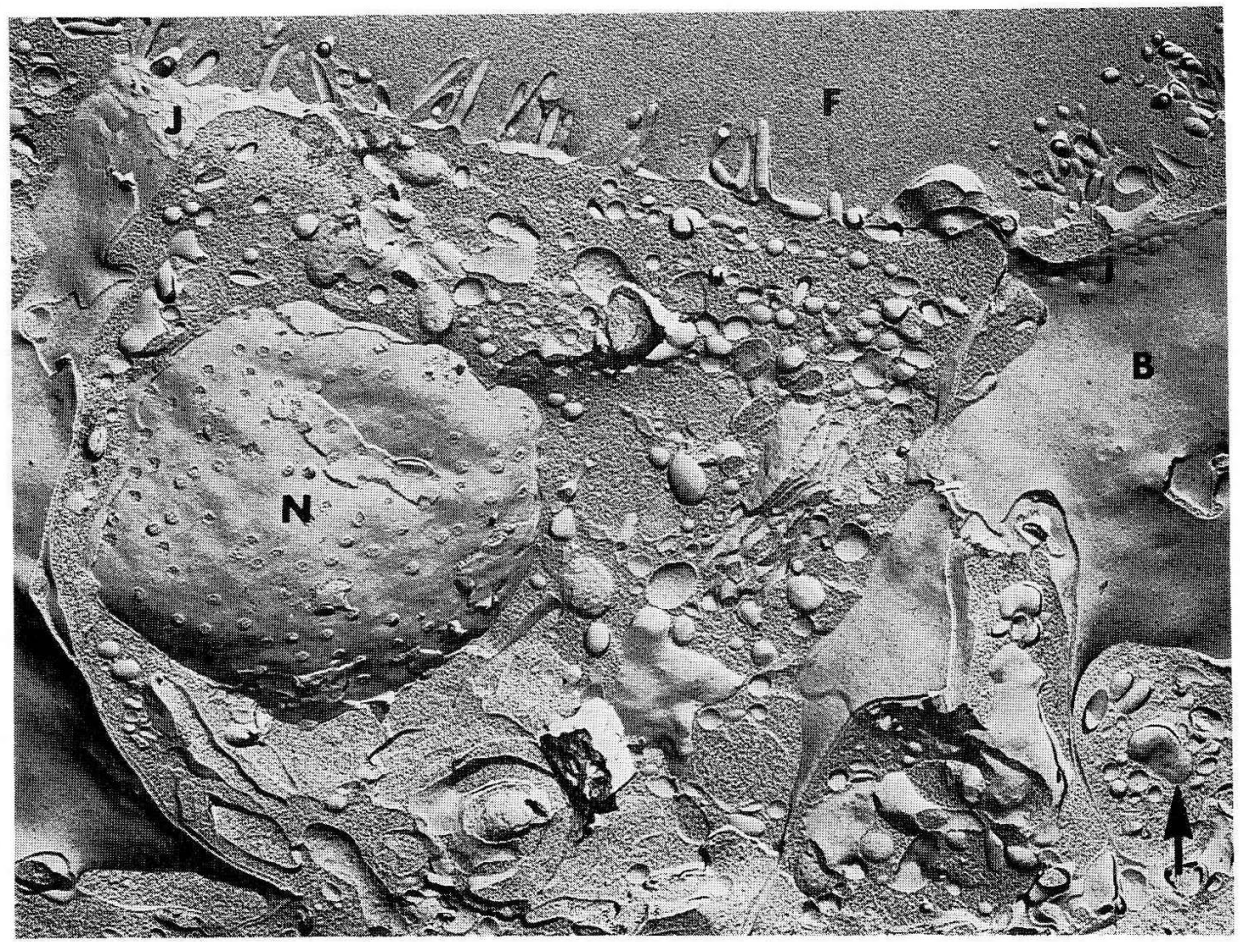

Fig. 1. A part of a normal rabbit thyroid. $F$ follicular lumen, $N$ nucleus, $B$ B face of the lateral plasma membrane, $J$ tight junction $\times 9,000$ 


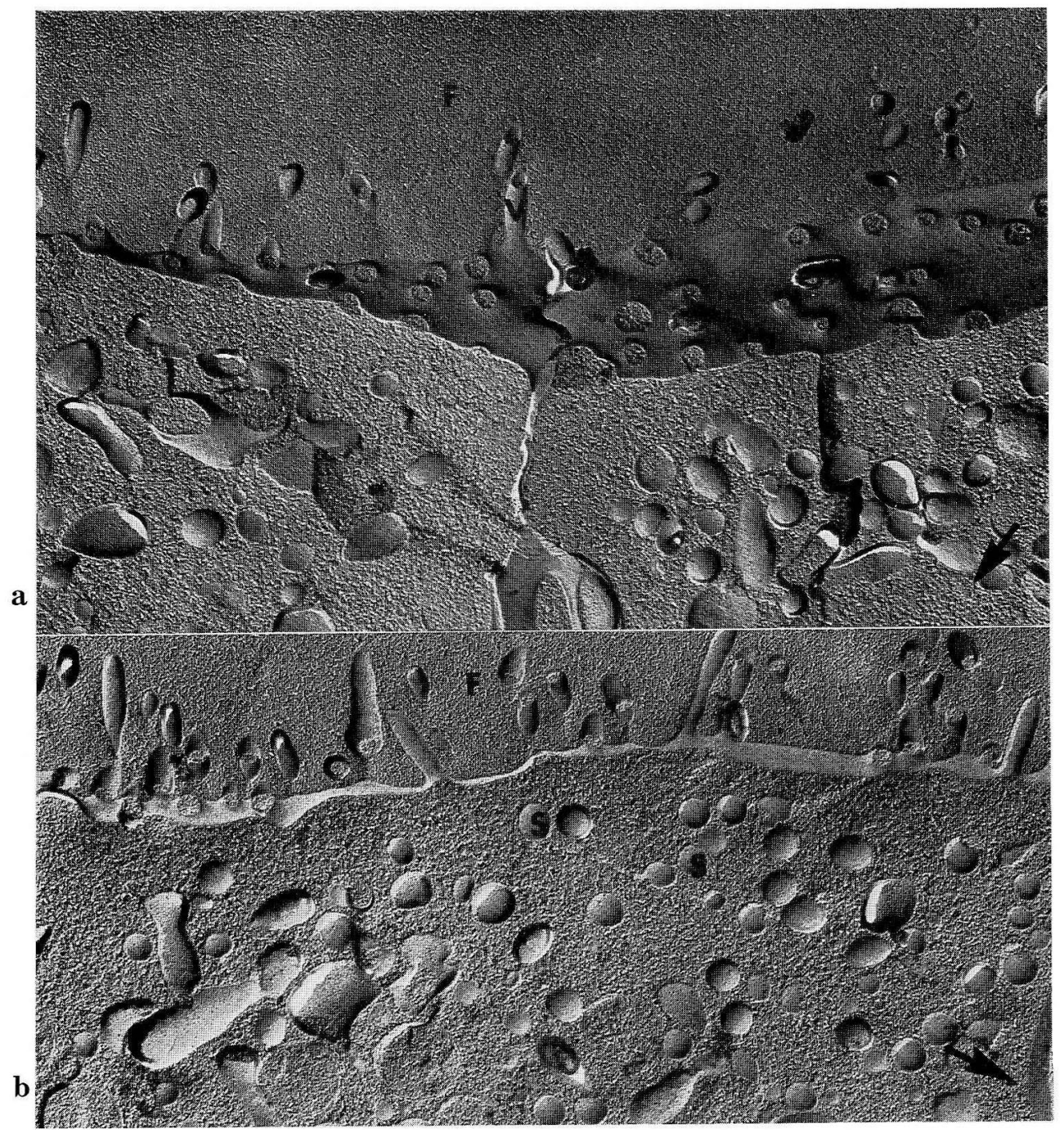

Fig. 2. Apical parts of the follicular epithelial cells of the normal rabbit thyroid. $F$ follicular lumem, $V$ microvilli, $S$ secretory granule. a : $\times 19,500, \mathbf{b}: 20,000$

Table 1. Measurements of the microvilli of rabbit follicular cells in freeze-etching electron micrographs

\begin{tabular}{ccccc}
\hline $\begin{array}{l}\text { Number of } \\
\text { microvilli } \\
\left(\text { per } \mu \mathrm{m}^{2}\right)\end{array}$ & $\begin{array}{c}\text { Diameter of } \\
\text { microvillus } \\
(\mu \mathrm{m})\end{array}$ & $\begin{array}{c}\text { Length of } \\
\text { microvillus } \\
(\mu \mathrm{m})\end{array}$ & $\begin{array}{c}\text { Surface area of a } \\
\text { microvillus } \\
\left(\mu \mathrm{m}^{2}\right)\end{array}$ & $\begin{array}{l}\text { Ratio of surface } \\
\text { areatof plasma } \\
\text { membrane including } \\
\text { microvilli to that } \\
\text { without microvilli }\end{array}$ \\
\hline $9.2 \pm 1.12^{*}$ & $0.13 \pm 0.048$ & $0.72 \pm 0.095$ & 0.307 & 3.70 \\
\hline
\end{tabular}

*standard deviation 


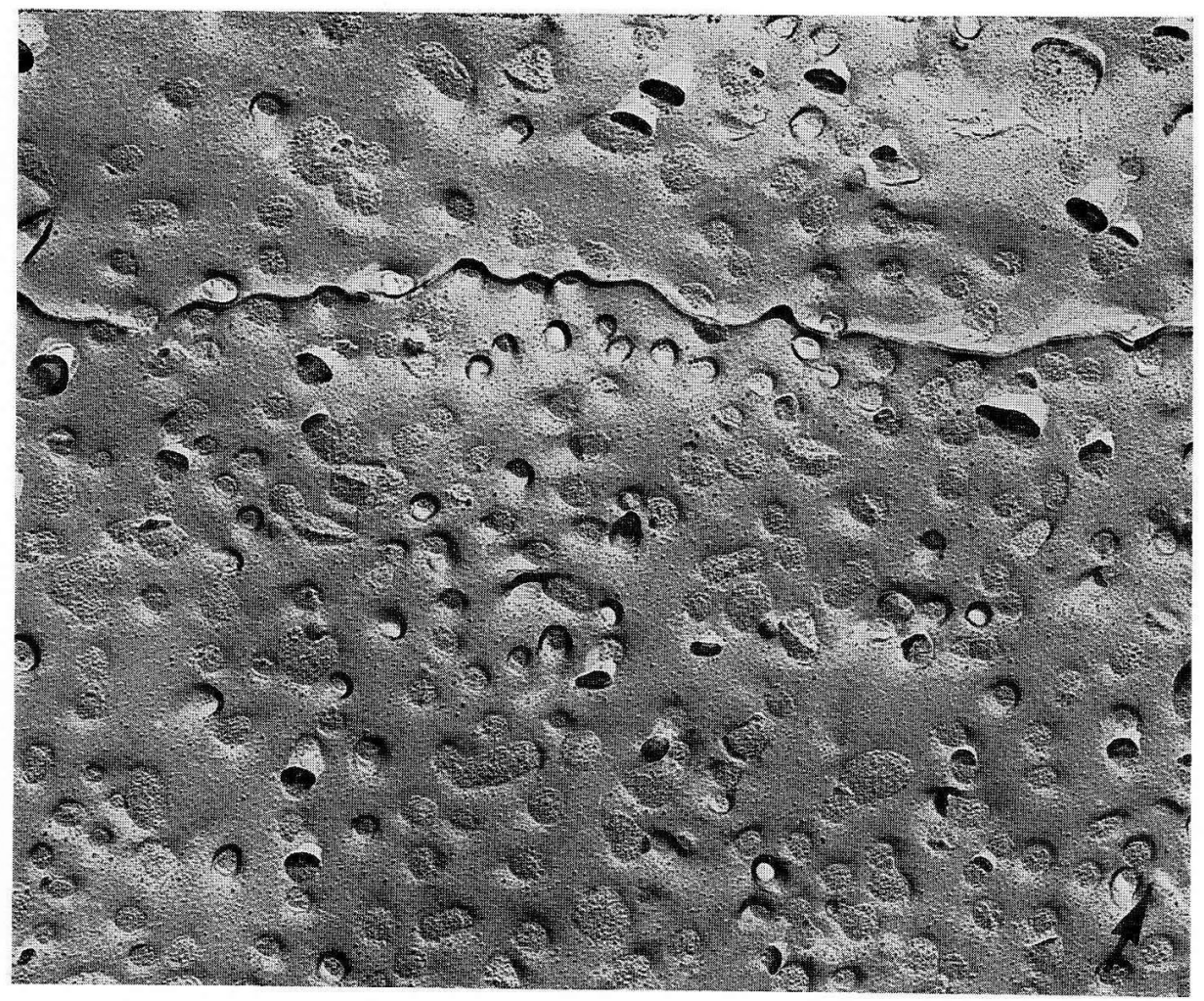

Fig. 3. B-face of the apical plasma membrane of the follicular epithelial cell of a rabbit thyroid. Notice numerous microvilli. $\times 19,000$

\section{Subapical junctional complex}

The A-face of the apical as well as lateral plasma membrane including that of microvilli shows numerous intramembranous particles of 150-200 $\AA$ diameter, while those on the B-face are smaller in number (Fig. 5). At the subapical part of the lateral plasma membrane is the typical tight junction reported in other organs by Friend and Gilula (1972), and Claude and Goodenough (1973) (Fig. 4). Interconnected ridges are seen on the A-face and grooves on the B-face as reported in the epithelium of other organs (KREUtziger, 1968; Staehelin et al., 1969; Goodenough and Revel, 1970; Friend and Gilula, 1972; Claude and Goodenough, 1973). The overall junctional depth is $0.3-1.1 \mu \mathrm{m}(0.52 \pm 0.04 \mu \mathrm{m})$ and there are 5 or more $(8.4 \pm 0.74)$ strands interposed between the luminal and the lateral plasma membranes (Table 2). The strands run irregularly making well developed anastomoses with one another. The number of strands and the depth of the tight junction in this case belong to the "very tight" form classified by CLAUde and Goodenough (1973). In addition to these, aggregates of intramembranous particles which mean gap junctions are often seen to be confined by ridges of the tight junction (Fig. 4). The tight junctions coexist with the gap junctions in the follicular epithelial cell of the rabbit. 


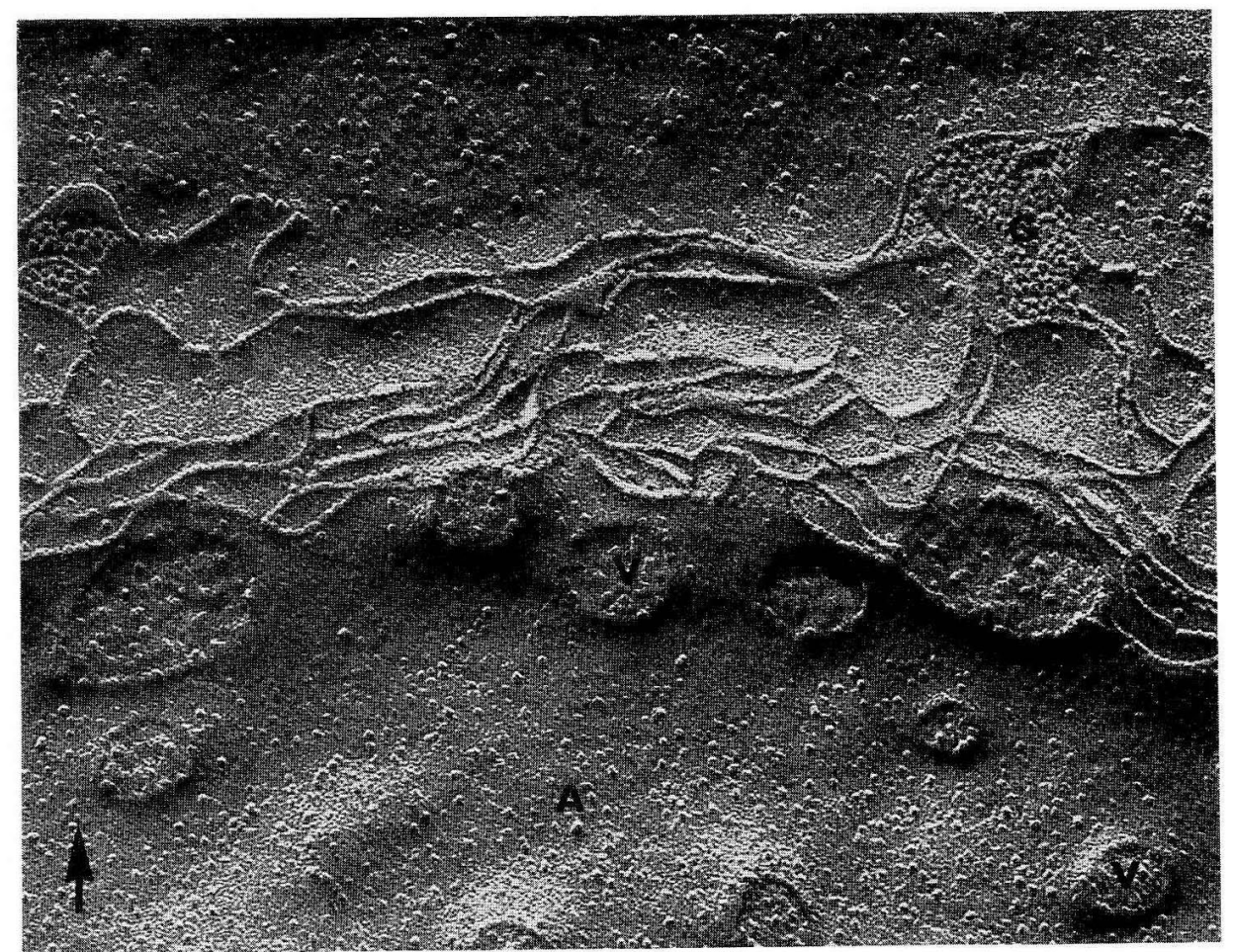

Fig. 4. Tight junction and gap junction $(G)$ of the follicular epithelial cell. Ridges and particles are noticed on the A-face. $L$ lateral plasma membrane (A-face), $A$ apical plasma membrane (Bface), $V$ microvilli $\times 78,000$

Table 2. Measurements of junctional structures of the rabbit thyroid follicular cells.

\begin{tabular}{cc|cc}
\hline \multicolumn{2}{c|}{ Number of strands } & \multicolumn{2}{|c}{ Depth of junction } \\
\hline range & mean \pm SE & range $(\mu \mathrm{m})$ & mean \pm SE $(\mu \mathrm{m})$ \\
\hline $5-16$ & $8.4 \pm 0.74$ & $0.3-1.1$ & $0.52 \pm 0.04$ \\
\hline
\end{tabular}

SE: standard error. Measurments were made parallel to the luminal surface every $0.3 \mu \mathrm{m}$

\section{Limiting membrane of reabsorbed colloid}

It has been well known that the intracellular large droplet $0.5-4.0 \mu \mathrm{m}$ in diameter is a reabsorbed colloid from the follicular lumen (SHELdon et al., 1964; WoLlmaN et al., 1964; Wetzel et al., 1965; Ekholm and Smeds 1966; Seluelid, 1967; Fujit a, 1969). In TSH-treated animals, cytoplasmic pseudopods and large or small colloid droplets appear in the apical part of the cytoplasm. Numerous intramembranous particles 150-200 $\AA$ in diameter are seen on the A-face of the limiting membrane of most large droplets and a few on the B-face in the TSH-treated animals (Fig. 6). The population density of the particles on the A-face of the limiting membrane of the droplet is 


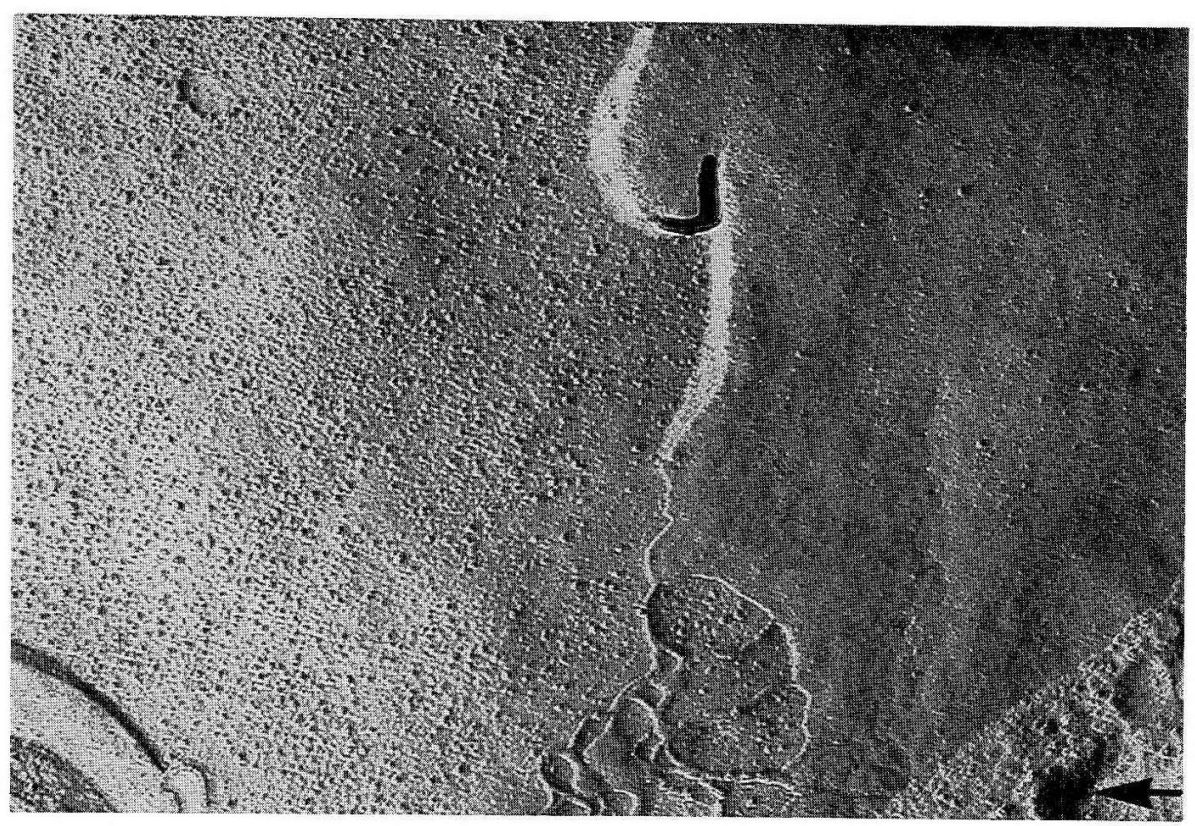

Fig. 5. A-face (left) and B-face (right) of the lateral plasma membrane. $\times 42,000$

Table 3. Number of intramembranous particles per $\mu \mathrm{m}^{2}$ on the A-face and B-face of the plasma membrane of the follicular epithelial cell and of the limiting membrane of the reabsorbed colloid droplet.

\begin{tabular}{l|cc}
\hline & A-face & B-face \\
\hline Apical plasma membrane & $570 \pm 45.4^{* *}$ & $1.30 \pm 20.3$ \\
\hline Lateral plasma membrane & $539 \pm 30.7$ & $105 \pm 10.7$ \\
\hline $\begin{array}{l}\text { Limiting membrane of reabsorbed } \\
\text { colloid droplet* }\end{array}$ & $500 \pm 42.3$ & $152 \pm 18.4$ \\
\hline
\end{tabular}

* In each colloid droplet, the number of the intramembranous particles in a concentric circle whose diameter is one third of the droplet is calculated.

** Standard deviation

almost the same as that on the A-face of the lateral and apical plasma membrane (Table 3, Fig. 5, 6).

\section{Endothelial cells}

The capillary endothelial cells of the rabbit thyroid are known to be the fenestrated type (Fig. 7). There are numerous fenestrations and vesicular stomatae on the A-face and B-face of the endothelial plasma membrane. In some parts of the endothelium the fenestrations are quite numerous, and in others such as the parajunctional zone they are very few in number. The population density of the fenestrations is about $20 / \mu \mathrm{m}^{2}$ on the endothelial surface except the parajunctional zones 


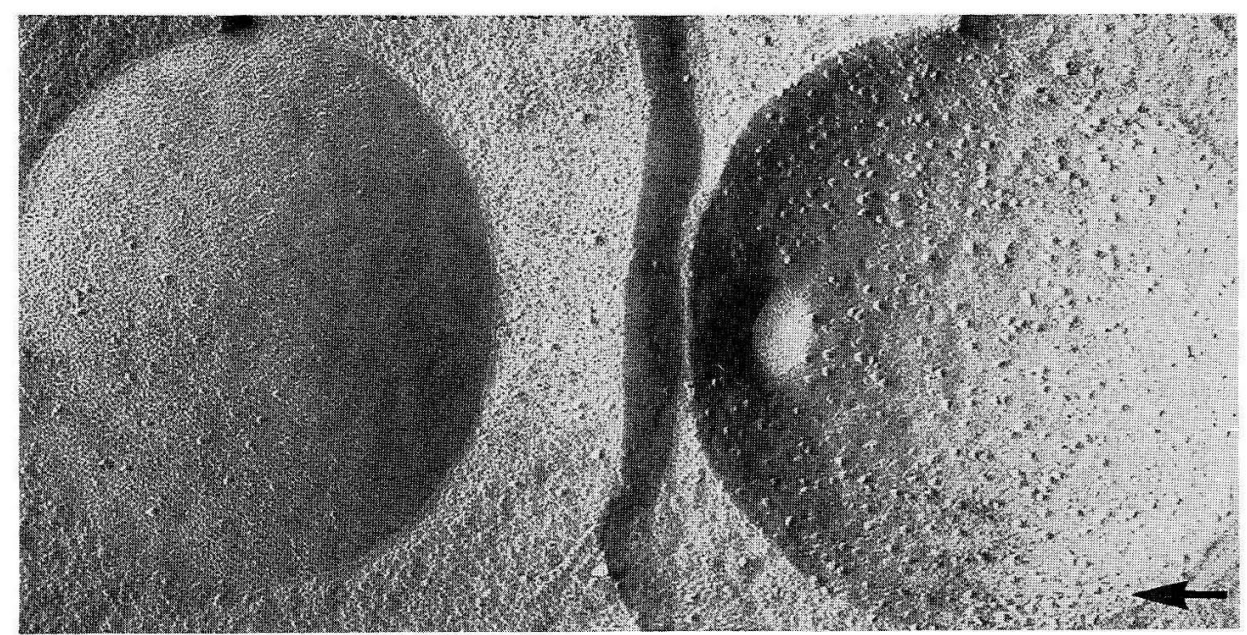

Fig. 6. A-face (right) and B-face (left) of the limiting membrane of reabsorbed colloid droplets in the follicular epithelial cell of the rabbit $1 \mathrm{hr}$ after injection of $5 \mathrm{IU}$ TSH. $\times 57,500$

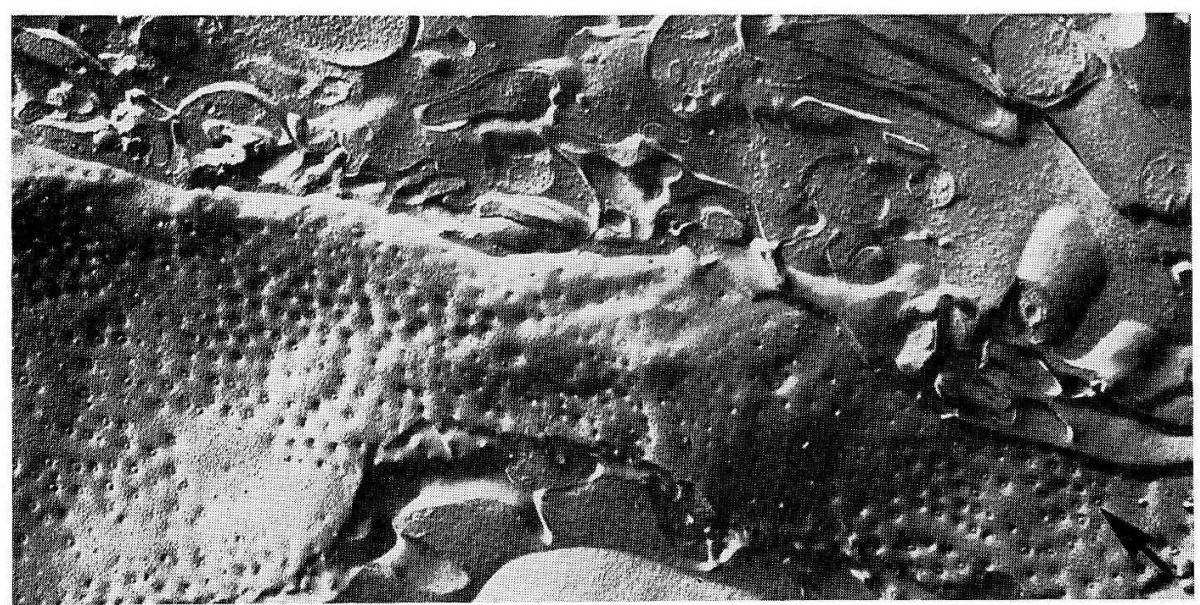

Fig. 7. Capillary endothelium of the normal rabbit thyroid. Notice numerous fenestrations on the A-face of the endothelial plasma membrane. $\times 9,500$

in the normal rabbit. The A-face of the endothelial plasma membrane has numerous intramembranous particles, while the B-face has fewer in number.

\section{Discussion}

The structure of the junctional complex in the thyroid epithelium deserves discussion. General freeze-etching images of tight as well as gap junctions have been described by many investigators (KreutzIGER, 1968; ST AEHELIN et al., 1969; ChalcrofT and Bullivant, 1970; Goodenough and Revel, 1970; McNutt and Weinstein, 1970; Friend and Gilula, 1972; Claude and Goodenough, 1973; Wade and Karnovsky, 1974). Claude and Goodenough (1973) classified the junctional complex of epithelia 
into 5 types: very leaky, leaky, intermediate, intermediate to tight, and very tight. According to them, the "very tight" junction has 4-11 strands and measures $0.3-1.1$ $\mu \mathrm{m}$ in depth. In the present study, the number of the strands is $5-16$ and the depth of the junction is $0.3-1.1 \mu \mathrm{m}$ in the thyroid epithelium of the rabbit. This result indicates that the junctional complex of the thyroid follicular epithelium belongs to the category of "very tight" in its morphology. Occasional leak of the luminal colloid is well known to be one of the causes for the formation of serum antibody against thyroglobulin, and so the junction of the thyroid follicular epithelium must be very tight physiologically.

An other interesting fact is the occurrence of aggregates of intramembranous particles indicating the gap junction in the same region. FrIEnd and Gilula (1972) reported that the epithelia of exocrine glands such as pancreas and liver have moderate-sized tight junctions and large gap junctions, and the adrenal cortex does not have a tight junction but possesses large gap junctions. KRISTic (1974) also reported that the pineal gland shows large gap junctions without a tight junction. The thyroid hormones such as $T_{3}$ and $T_{4}$ are released from the basal part of the cell into the pericapillary space, but thyroglobulin is secreted into the follicular lumen from the apical part. The former belongs to the endocrine secretion of the thyroid hormone, while the latter to the exocrine-like secretion if the follicular lumen is regarded as the secretory duct. The epithelial cells of the thyroid are arranged in the form similar to those of exocrine glands, and the junctional complex of the thyroid is similar in morphology to that of exocrine organs such as the pancreas and liver which has been reported by FRIEND and Gilula (1972), though the depth of the junction in the thyroid is somewhat larger than in the exocrine organs. The limiting membrane of the intracellular large colloid droplet which is considered to contain a reabsorbed material shows a very similar pattern to that of the plasma membrane in the distribution of intramembranous particles on the A- and B-face. The particles on the A-face are more numerous than those on the B-face. The luminal colloid has been known to be reabsorbed into the cell by endocytotic procedures such as pinocytosis or phagocytosis (Wetzel et al., 1965; SelJelid, 1967). Hence, the limiting membrane of the reabsorbed colloid is derived from the apical plasma membrane of the follicular epithelial cell. These facts seem to account for the present finding that the distribution of the intramembranous particles on the A- and B-faces of the reabsorbed colloid droplet are very similar to that of the plasma membrane.

The blood capillary in the mammalian thyroid has been known to be of fenestrated type (Екноцм, 1957; Wissig, 1960; Fujita, 1963 and others) and numerous fenestrations are recognized also in the freeze-etching image. The structure of the capillary endothelium in the mouse thyroid is quite similar to that in the pancreas and jejunal mucosa reported by Simionescu et al. (1974).

Acknowledgement. The authors would like to express their hearty thanks to Mr. N. Kanda for his technical assistance. 


\title{
イエウサギ甲状腺のフリーズーエッチング像
}

\author{
藤田尚男, 三嶋弘, 大塚長 康
}

イエウサギ甲状腺のフリーズーエッチング像を電子顕微鏡で観察した. フリーズーエッチ ング法による甲状腺濾胞上皮細胞の構造の概観は，超薄切片法で観察した構造とよく一致 していた。濾胞上皮細胞間の上端の接着複合体は，閉鎖帯 (tight junction) とギャップ結 合 (gap junction) の共存から成り立っている. 閉鎖帯の線條の数（5-16）と線條の存する 帯の上下の幅 $(0.3-1.1 \mu \mathrm{m})$ から，滤胞上皮細胞間の閉鎖帯は，ClAUdE と GOOdENOUGH の 分類にあてはめると，非常に強固 (very tight) な閉鎖帯にあたる．濾胞腔内のコロイドの 濾胞外一のもれ它強く防いでいると考えられる. 細胞側面の細胞膜のA面における膜内粒

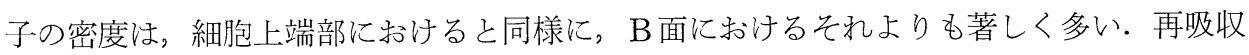
されたコロイド滴の限界膜も，膜内粒子の密度において 原形質膜のそれと同じパターン をとり，A面の粒子の数が B面のそれと比べてはるかに多い。毛細血管内皮細胞では 接 着部の周囲の領域它除いて 多数の空が見られた (約 $\left.20 / \mu \mathrm{m}^{2}\right)$.

\section{References}

Buchheim, W. und U. Welsch : Die Feinstruktur gefriergebrochener Hormongranula. Z. Zellforsch. 131: 429-436 (1972).

Chalcroft, J. P. and S. Bullivant: An interpretation of liver cell mambrane and junction structure based on observation of freeze-fracture replicas of both sides of the fracture. J. Cell Biol. 47: 49-60 (1970).

Claude, P. and D. A. Goodenough : Fracture faces of zonulae occludentes from tight and leaky epithelia. J. Cell Biol. 58: 390-400 (1.973).

Ekholm, R. and S. Smeds : On dense bodies and droplets in the follicular cells of the guinea pig thyroid. J. Ultrastr. Res. 16: 71-82 (1966).

Friend, D. S. and N. B. Gilula : Variations in tight and gap junctions in mammalian tissues. J. Cell Biol. 53: 758-776 (1972).

Fujita, H.: Studies on the iodine metabolism of the thyroid gland as revealed by electron microscopic autoradiography of ${ }^{125}$ I. Virchows Arch. B Cell Pathol. 2: 265-279 (1969).

Goodenough, D. A. and J. P. Revel: A fine structural analysis of intercellular junctions in the mouse liver. J. Cell Biol. 45: 272-290 (1970).

Kreutziger, G. O.: Freeze-etching of intercellular junctions of mouse liver. Proc. 26th Electron Microsc. Soc. Amer. 234 (1968).

Kristić, R.: Ultrastructure of rat pineal gland after preparation by freeze-etching technique. Cell Tiss. Res. 148: 371-379 (1974).

MeNutt, N. S. and R. S. Weinstein : The ultrastructure of the nexus. A correlated thin-section and freeze-cleave study. J. Cell Biol. 47: 666-688 (1970).

Moore, H. and K. Mühlethaler: Fine structure in frozen etched yeast cells. J. Cell Biol. 17: 609-628 (1963).

Saljelid, R.: Endocytosis in thyroid follicle cells. II. A microinjection study of the origin of colloid droplets. J. Ultrastr. Res. 17: 401-420 (1967). 
Sheldon, H., J. M. McKenzie and D. van Nimwegan : Electron microscopic autoradiography. The localization of ${ }^{125} \mathrm{I}$ in suppressed and thyrotropin-stimulated mouse thyroid gland. J. Cell Biol. 23: 200-205 (1964).

Simionescu, M., N. Simionescu and G. E. Palade: Morphometric data on the endothelium of blood capillaries. J. Cell Biol. 60: 128-152 (1974).

Staehelin, L. A., T. M. Mukherjee and A. W. Williams: Freeze-etch appearance of tight junctions in the epithelium of small and large intestine of mice. Protoplasma 67: 165-184 (1969).

Wade, J. B. and M. J. Karnovsky : The structure of the zonula occludens. A single fibril model based on freeze-fracture. J. Cell Biol. 60: 168-180 (1974).

Wetzel, B. K., S. S. Spicer and S. H. Wollman : Changes in fine structure and acid phosphatase localization in rat thyroid cells following thyrotropin administration. J. Cell Biol. 25: 593-618 (1965).

Wollman, S. H., S. S. Spicer and M. S. Burstone : Localization of esterase and acid phosphatase in granules and colloid droplets in rat thyroid epithelium. J. Cell Biol. 21: 191-201 (1964).

藤田尚男

₹734 広島市霞1-2-3

広島大学医学部

第二解剖学教室
Prof. Hisao Fujita

Department of Anatomy

Hiroshima University School of Medicine

Hiroshima, 734 Japan 